\title{
Chapter 32 \\ Old-Age Digital Exclusion as a Policy Challenge in Estonia and Finland
}

\author{
Anu Leppiman, Iivi Riivits-Arkonsuo, and Anneli Pohjola
}

\subsection{Introduction}

Conceptualisations of social exclusion increasingly recognise the significance of digital forms of exclusion. As a consequence, responding to the digital divide has become a key social and policy challenge in contemporary society (Helsper 2012; Martin et al. 2016). The coincidence of increasing longevity and widespread digitalisation characterise all European Union member states, including countries such as Estonia and Finland. This requires effective strategies in both the economic and social spheres (Batut 2016). This chapter aims to explore the challenges posed by digitalisation for ageing populations, the concerns experienced by older people when accessing digital services, and the key elements of digital solutions that are designed to answer older people's needs. We consider these issues in the specific context of Estonia and Finland, as countries that are close to one another as states and nations. At almost all levels and sectors of society, the relations between the two countries are intense. Estonia, like Russia and the Ukraine included elsewhere in this section of the book, is a post-socialist state with a welfare model that differs from Finland. The social structure in Estonia emphasises the principles of individual self-responsibility and self-regulation as well as a government that seeks to avoid interference in individuals' affairs (Leppiman and Tulva 2005). While Estonia has adopted a liberal model, with the hallmarks of a US-style welfare system based on neoliberal and monetarist economic thinking, Finland is typically characterised as having a Nordic welfare state regime. However, in recent times market-liberal thinking has increasingly penetrated the public sector and this trend seems to be

\footnotetext{
A. Leppiman $(\varangle) \cdot$ I. Riivits-Arkonsuo

Tallinn University of Technology, Tallinn, Estonia

e-mail: anu.leppiman@taltech.ee
}

\author{
A. Pohjola \\ University of Lapland, Rovaniemi, Finland
}


continuing in Finland, giving rise to problems in linking the market economy and public sector activities (Koskiaho and Saarinen 2019).

As in other nations, the populations of Finland and Estonia are ageing rapidly, with increasing life expectancy contributing to a growth in the numbers and proportions of older people. In Finland, the age groups born after the Second World War are disproportionately large, and Finland is characterised by its high numbers of older people. Over one-fifth of Finland's population (5.5 million) is over 65 years (1.2 million/22\%), and an increasing proportion are over 75 years (Statistics Finland 2019). In Estonia, the birth rate after the Second World War was more modest. However, nearly one-fifth (19.6\%) of the Estonian population (1.3 million) is over 65 years of age (Statistics Estonia 2019). At the same time, in both countries, the younger age groups are shrinking as a result of low birth rates.

In Estonia and Finland, the use of technology and digital services has become widespread in the public and private sectors. These countries are building a digital society and digitising public services both nationally and across borders. Estonia's and Finland's data exchange layers are connected to one another, enabling crossborder data exchange (Nordic Institute for Interoperability Solutions 2019). However, population ageing poses a fundamental challenge in relation to digitalisation. The rapid growth of Information and Communication Technologies (ICT) facilitates people's lives and offers a variety of digital services. People who have the necessary skills and motivation to use ICTs can benefit considerably from inclusion within a digital society. Digitalisation enables people to learn and to be proactive, especially when they are older and their mobility is reduced. It can help to avoid segregation and facilitate knowledge transfer (Batut 2016). Delivery of digital services influences positively the life of older people, improves quality of life and increases independence (Czaja 2017; Siegel and Dorner 2017). Nevertheless, digital technologies can also have their drawbacks. Not all people have equal access to digital services, resulting in widespread exclusion and the emergence of a digital divide between different user groups (Ihm and Hsieh 2015; see also Poli et al. this volume for a related analysis of old-age digital health exclusion).

In particular, older adults who are economically, socio-culturally, or physically disadvantaged are at risk of being marginalised (Grundy 2006; Yu et al. 2016). For them, digital exclusion, access to information and difficulties in accessing online services can cause problems, uncertainty and insecurity. Drawing on the conceptual model of social exclusion in later life developed by Walsh et al. (2017), where digital exclusion is a feature of the services, amenities and mobility domain, poor accessibility and usability of digital technologies can create barriers for some older people, resulting in their exclusion from the opportunities presented by digitalisation (Yu et al. 2016; Niemi 2017).

Public policy can play a major role in reducing digital exclusion among older people, depending on what kind of values and whose needs are placed at the centre of the policy-making process. It is important for policy to address the risk of exclusion faced by older people who are unable to use the Internet or access e-services when using services and participating in civic activities. Moreover, both the 
availability and quality of digital services designed for older people are highly dependent on policy decisions.

\subsubsection{Multiple Causes of Digital Exclusion}

Older people are a heterogeneous group with different capacities and abilities to act. While they are not a separate category to consider, it is necessary to identify the spectrum among them and ongoing changes in their life situations. Older people are characterised by differences in their economic, educational, social and societal roles. It is not only important to take into account the contextual factors of their lives, but also the human and social capital at their disposal (Niemi 2017).

Old-age exclusion involves interchanges between multilevel risk factors, processes and outcomes (Walsh et al. 2017), with digital exclusion representing a key form of exclusion in later life. Older-age is typically associated with a reduced likelihood of using online services (Freese et al. 2006; Sourbati 2007) and older people tend to be on the wrong side of the digital divide (Olphert and Damodaran 2013; Friemel 2016). Digital exclusion can have multiple causes, related to a lack of the fundamental requirements for the democratisation of technology: hardware access (affordability, availability of energy networks), access to the Internet (affordability, availability of infrastructure to connect to a network), and mastery of technology (Castilla et al. 2018). Moreover, commonly identified reasons for old-age digital disengagement include disability, complexity of the technology, social isolation, lower income, and lower education (Olphert and Damodaran 2013; Friemel 2016). Older adults are more likely to be late rather than early adopters of technologies (Chen and Chan 2014). In addition to socio-demographic factors, psychological factors contribute strongly to the digital divide affecting the older population. Older people who feel younger than their chronological age, experience less technology anxiety, feel more confident in using technology, and are more adventurous are more likely to be active participants in a digital society (Peral-Peral et al. 2015).

New technologies have emerged with the rapid expansion of the Internet into modern life. In this regard, older people are more susceptible to certain fears than younger, so-called "digital natives". Older adults are more susceptible to technology anxiety, such as: a concern that technology will be complicated to use; it will intrude into their private life; they may be a victim of fraud if they make online payments; technology is dangerous (Batut 2016).

As suggested by Michael Cahill (1994), digital exclusion is associated with the emergence of new forms of poverty that became social policy challenges even before the ICT revolution. According to Cahill, the new forms of poverty produced by the era are, for example, information and communication poverty and service poverty. Older people are required to stay abreast of the ever-growing knowledge, interpretation, media literacy and digital skills of services, communication with multiple actors, and the maintenance of social relationships. Otherwise, they are in danger of being excluded from access to information and services and are outside of 
channels which they could influence. The new forms of poverty described by Cahill (1994) are intertwined with the demands of the digital world.

\subsubsection{Digitalisation as a Process of Social Change}

Digitalisation of society is advancing at a faster pace than people are able to embrace the new technological applications. Hardware, software and operating systems are constantly evolving, and new learning is required all the time. The ability to get used to continuous and consistent change and up-dates in ICT equipment and software presents challenges for younger people as well as older people. The more information technology facilitates everyday life, the higher is our dependence on it (Leppiman 2010). The Internet user penetration rate continues to grow year on year. By 2024, it is predicted that there will be an internet usage rate of $97.5 \%$ in Finland (Statista 2018). In Estonia, the objective is to increase the percentage of Internet users among the entire population by 2020 , from the current figure of $88-95 \%$ (Chancellor of Justice 2019).

Digitalisation has not only become a part of society, but is itself constantly and profoundly changing social development. Indeed, digitalisation is an important and fast-paced process of social change that affects the daily lives of all age groups. It aims at streamlining people's lives, disseminating information, facilitating transactions, delivering services, and increasing inclusiveness, social relationships and networking. It should be about new opportunities created by digitalisation. From a human point of view, the key is how technology can be developed so that it contributes to the smooth running and well-being of people.

According to Finnish statistics, $74 \%$ of $65-75$ year-olds have used the Internet and $21 \%$ have accessed some type of digital service. The corresponding figures for the older-age group (75-89 years) are 31\% and 8\% respectively, leaving a significant majority of older adults excluded from digital activities. By comparison, almost all people of working age (16-64 years) use the Internet (Statistics Finland 2016). In Estonia, there is also evidence of a digital divide between people aged 15-60 years (internet usage rate: $96 \%$ ) and older-age groups. A representative national survey showed that $62 \%$ of people aged $60-74$ years use the Internet compared to only $25 \%$ of people over 75 years (Turu-uuringute AS 2019).

The age-related differences in the use of digital technology are significantly influenced by the lack of previous experiences and the alienation of operating logic for hardware, software and network services (Päykkönen 2017). Older-age groups have become socialised in the technology of each era in their generational history and encountered a breakthrough in information technology relatively late in their life course. Furthermore, they have often been out of the labour market for a long time, and do not have either user experience or IT supporting structures. Individual life histories differ concerning the use of technology (Niemi 2017; Koskiaho and Saarinen 2019). 
The goals of digitalisation often reflect the long-term future of society, but are expected to be realised in practice in today's society. However, reality does not necessarily come with the kind of comprehensive and rapid digital transformation that we are expecting. In Finland, for example, it is estimated that half a million citizens experience a range of barriers to using e-services (Kestilä and Karvonen 2019). For older people, it is estimated that as many as one million are resistant to adopting digital services (VM 2017) and more than half a million do not use the Internet at all (Statistics Finland 2016). The figures indicate a significant problem of structural exclusion, even though the use of digital applications and the digital inclusion of the ageing population is constantly expanding. However, at the same time, the diversity, incompatibility and complexity of digital applications is also increasing (Pohjola 2017).

\subsubsection{Digital Services: Seeking Simplification and Efficiency}

While ICT has reduced and improved operations in commercial businesses, digitalisation also reduces the number of touchpoints and limits interaction time between providers and customers (Kukk and Leppiman 2019). All organisations are looking for ways to manage and allocate their funding in the most efficient way. Service providers, when faced by the high costs of maintaining traditional services, will strive in their business processes for the simplification and efficiency that digitalisation enables. One of the most characteristic examples of digitalisation is reflected in the shift towards digital banking. For the past two decades, commercial banks have been closing physical branches. Customers increasingly need to use online channels to stay in touch with their banks, transfer money, check balances, and pay bills. Digital solutions are available to everyone faster than ever before, regardless of time and location. Lack of digital devices, such as personal computers, tablets or smartphones, or lack of skills needed for using them, places part of the population in an unequal position. Older people are expected to use personal computers and smartphones, even though the usage of such devices is much lower among older compared to younger age groups.

In Estonia, the healthcare system has been revolutionised by innovative e-solutions. Patients can view their personal medical data in the Patient Portal, see prescribed medicines and prescriptions' validity and schedule a doctor's appointment. People can also view their pension and social welfare entitlements online. Likewise, in Finland, social services, healthcare services and functionalities are highly digitalised, with a range of e-health services available for citizens (Vehko et al. 2019).

A prerequisite for making the most of these opportunities is internet access and the ability to access digital services. People who lack access are left without corresponding information. It is already taken for granted that welfare information and services are increasingly produced digitally. At the same time, face-to-face services are being minimised for cost reasons and traditional local services are being reduced. When digitalising services, the automatic assumption is that everyone is able and 
willing to use electronic services instead of having a personal meeting. Along with financial savings, the idea is that almost everyone uses the Internet. However, such assumptions do not specify the scale, level or quality of internet use, for example, among people in different stages of ageing. The reasoning is based on generalisations. Market-liberal thinking emphasises individual responsibility, which includes the obligation to stay involved in change, self-responsibility and self-direction, selfservice and self-care.

Older people, comprising a population segment typically seen as being more vulnerable to social isolation during the later stages of life, are often more likely to be excluded from the focus of ICT research (Ihm and Hsieh 2015). Statistics Estonia, commissioned by the Ministry of Economy, carries out a household internet usage survey, in the framework of which only people up to 74 years of age are questioned. The survey's objective is to gather data about information technology devices and internet usage among residents of Estonia. Thus, older people, who make up $10 \%$ of Estonia's population, are excluded from the survey on internet use. The data from internet usage surveys are used to develop and implement the development plan for Estonia's information society. Moreover, collected data are used to develop and design digital services. Considering such needs, the Chancellor of Justice advises the Statistical Office to also collect internet usage data from people older than 74 years of age (Chancellor of Justice 2019). By disregarding one-tenth of the population, the bias in such data collection may lead policy makers and commercial organisations to over-estimate the number of people who can access online services, and to under-estimate the need for alternative delivery channels and support (Olphert and Damodaran 2013).

One of the reasons why older people are prone to digital exclusion is that their needs and experiences are ignored. In this context, relatively little is known about how older people are embracing constantly evolving digital innovations and how they adapt to rapid change. Against this background, several questions arise. For instance, what does it mean when services are provided by mobile apps? Are websites providing e-services user-friendly, including for older adults? How easy is it to navigate websites to find the services or other information that people need?

Our view is that the needs of older users are often ignored in the shift towards digital services. This happens not only in Estonia and Finland, but also elsewhere because digital service users are not involved and not engaged in the co-creation of the service. The situation is aggravated by the fact that technology applications are being developed separately from the user experience, whereby technology is driven by technology instead of user control. This gives rise to technology determinism, in which digitalisation seems to become a self-governing actor, a goal or a value in itself, rather than a tool for society to achieve its goals. Services are largely developed on the basis of digital solutions, with an instrumental and organisational focus, whereby customers' everyday needs are neglected. Older people will have to adapt to a constantly changing technological environment, rather than adapting technology to the needs and capabilities of older people (Pohjola 2017).

Typically, digital service providers, designers and developers represent younger age-groups who find it difficult to understand the needs of older people 
[see Poli et al. this volume for a discussion of the exclusion of older people from design processes]. The perceptions of different age cohorts are based on their own experiences. Service designers belonging to the youngest age groups may find it challenging to understand the needs of the older user and their customer journey.

\subsubsection{Discussion}

Digital forms of exclusion are part of a wider pattern of exclusion that affects people in later life. The challenge for policy makers wishing to reduce social exclusion in general is to place a stronger focus on reducing exclusion from digital technologies. Given the progressive ageing of Europe's populations and the associated shrinking populations of working-age, societies are increasingly cautious when using public funds. As a consequence, the European Economic and Social Committee argues that civil society representatives, including potential beneficiaries of innovations to maintain health and independence, should be included in dialogue arrangements (Batut 2016).

The issue of digital exclusion raises a fundamentally new social policy challenge if a significant and growing part of the population is not to be displaced by the increasing complexity and rapid social structural change. Matters of social responsibility need to be considered in relation to the situation of different population groups and in terms of digital accessibility. A socially sustainable digital society requires not only individual responsibility but also social solidarity in order to bridge the gap between population groups with differing degrees of access to and understanding of digital technologies.

The requirement of social responsibility is built on the fact that digital solutions are in any case social because they arise from human action. Technologies are merely platforms and tools for social action. The role of technologies is to bend the development of services to meet people's needs in order to support their well-being (Niemi 2017; Pohjola 2017). Key elements in the design of digital solutions for older people, as well as for other citizens, are shown in Fig. 32.1.

The starting point for designing a digital environment is to start with everyday practicalities (Koskiaho and Saarinen 2019). The goal is a human, workable everyday life and finding coping strategies. Everyday perspectives highlight the diversity of human social activity, its resources, networks and social capital. Digital solutions can, at best, support human social empowerment, deliver social support and inclusion, and reduce loneliness (Blazun et al. 2012), which in turn promote technology utilisation.

It is necessary to move from traditional technology- and organisation-oriented design to human-centred development (Leikas 2014) if we are to build solutions that are functional both for older people and for service providers. However, this often requires "interpreters", "translators" who are knowledgeable and informed about people's situations, such as social workers, who can help clarify needs and usability requirements. User-driven design is demand-driven and recognises the 
Fig. 32.1 Key elements of design for digital solutions

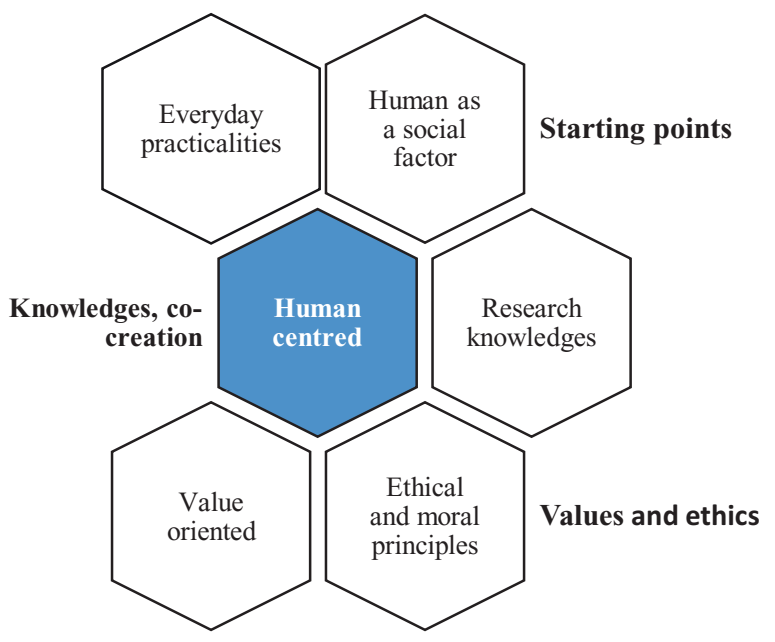

various factors that influence human-technology interaction, as well as people's different capabilities and conditions (Niemi 2017). At its best, user-driven digitalisation provides accessible solutions for older people. The human-centred (user-driven) concept implies a co-creation process where the user should be seen as an expert on the context (that is problem, need for service, implication of the result) while the service provider is the expert on the solution created during the service (Pohjola 1993).

Planning would also require a much better research knowledge base. The use of ageing-related scientific knowledge in technology development is still limited. Research is needed on the fundamental issues of how digitalisation affects people's daily lives, and what benefits or disadvantages it brings to different groups of people in different contexts and the unintended consequences (Niemi 2017; Koskiaho and Saarinen 2019). In a similar vein, value orientation is also key to designing digital solutions. It includes the basic question of what kind of social actors older people are perceived to be. A dignified old-age is a human right (Leikas 2014). The perspective on ageing differs depending on whether older people are seen as active and functioning citizens, consumers, clients or as recipients of care and services. According to the European Economic and Social Committee (Batut 2016), digitalisation for older people should not be limited just to "technical/medical aid". That is, user inclusive policy refers to taking into account both the provider's perspective and needs regarding value co-creation and the user's view and expectations (Kukk et al. 2014). The focus on value orientation is to avoid producing stigma. Understanding the different ethical and moral issues in the use of technology in society is also essential. For example, awareness of the self-determination of older people and insight into their resources is needed. Ethics are at the heart of digital services design (Niemi 2017; Koskiaho and Saarinen 2019). 


\subsubsection{Conclusion}

Both in Estonia and Finland more effort and investment in digital solutions development is needed to ensure equal access to digital services. Policies can be shaped either to support the needs and values of older citizens as a target group or oriented mainly towards the needs and values of service providers. When it comes to reducing digital exclusion, we suggest that policy makers consider how best to find a balance between service-centred thinking and user (human)-centred understanding and implementation.

\section{Editors' Postscript}

Please note, like other contributions to this book, this chapter was written before the COVID-19 pandemic of 2020. The book's introductory chapter (Chap. 1) and conclusion (Chap. 34) consider some of the key ways in which the pandemic relates to issues concerning social exclusion and ageing.

\section{References}

Batut, L. (2016). Opinion of the European Economic and Social Committee on the digital pillar of growth: E-seniors, a potential 25 per cent of the European population. https://www.eesc. europa.eu/en/our-work/opinions-information-reports/opinions/digital-pillar-growth-e-seniorspotential-25-european-population. Accessed 8 Aug 2019.

Blazun, H., Saranto, K., \& Rissanen, S. (2012). Impact of computer training courses on reduction of loneliness of older people in Finland and Slovenia. Computers in Human Behavior, 28(4), $1202-1212$.

Cahill, M. (1994). The new social policy. Oxford: Blackwell.

Castilla, D., Botella, C., Miralles, I., Bretón-López, J., Dragomir-Davis, A. M., Zaragoza, I., \& Garcia-Palacios, A. (2018). Teaching digital literacy skills to the elderly using a social network with linear navigation: A case study in a rural area. Journal of Human Computer Studies, $118,24-37$.

Chancellor of Justice. (2019) Statistics Estonia should collect data on Internet usage by the elderly. https://www.oiguskantsler.ee/en/statistics-estonia-should-collect-data-internet-usageelderly. Accessed 16 Sept 2019.

Chen, K., \& Chan, A. H. (2014). Predictors of Gerontechnology acceptance by older Hong Kong Chinese. Technovation, 34(2), 126-135.

Czaja, S. J. (2017). The role of Technology in Supporting Social Engagement among Older Adults. Public Policy \& Aging Report, 27(4), 145-148.

Freese, J., Rivas, S., \& Hargittai, E. (2006). Cognitive ability and internet use among older adults. Poetics, 34(4-5), 236-249.

Friemel, T. N. (2016). The digital divide has grown old: Determinants of a digital divide among seniors. New Media \& Society, 18(2), 313-331.

Grundy, E. (2006). Ageing and vulnerable elderly people: European perspectives. Ageing \& Society., 26(1), 105-134. 
Helsper, E. J. (2012). A corresponding fields model for the links between social and digital exclusion. Communication Theory, 22(4), 403-426.

Ihm, J., \& Hsieh, Y. P. (2015). The implications of information and communication technology use for the social well-being of older adults. Information, Communication \& Society, 18(10), $1123-1138$.

Kestilä, L., \& Karvonen, S. (2019). Suomalaisten hyvinvointi 2018 [The welfare of Finns 2018]. Terveyden ja hyvinvoinnin laitos Helsinki: THL [Finnish Institute for Health and Welfare].

Koskiaho, B. \& Saarinen, E. (Eds.) (2019). Ihan pihalla? Vanhat ihmiset digitaalisen maailman myllerryksessä: neuvonnan, ohjauksen ja asioiden ajamisen järjestäminen [Old people in the turmoil of the digital world]. Helsinki: Soste, Suomen sosiaali ja terveys ry. [Finnish Federation for Social Affairs and Health].

Kukk, J., \& Leppiman, A. (2019). The significance of value-in experience in the age of digitalisation. In S. Miettinen \& M. Sarantou (Eds.), Managing complexity and creating innovation through design (pp. 132-140). London: Routledge.

Kukk, J., Leppiman, A., \& Pohjola, A. (2014). Designing a business service experience: customer's perspective on value co-creation. Journal of Research in Economics and Business: Central and Eastern Europe, 6(1), 51-64.

Leikas, J. (Ed.). (2014) Ikäteknologia [Aging and Technology]. Tutkimuksia 2/2014. Helsinki: Vanhustyön keskusliitto [The Finnish Association for the Welfare of Older People].

Leppiman, A. \& Tulva, T. (2005). Entwicklung und Probleme der Sozialarbeit in Estland nach der Wiedererlangung der Unabhängigkeit [Development and Problems of Social Work in Estonia after Regaining Independence]. - Soziale Arbeit im öffentlichen Raum, Soziale Gerechtigkeit in der Gestaltung des Sozialen. Berlin: VS Verlag für Sozialwissenschaften, 19. [CD-ROM].

Leppiman, A. (2010). Arjen Elämyksiä - Leiri-ja elämyspohjainen Arkipäivät Perhepalvelu Sosiaalisen Kokemuksen Tuottajana [Everyday Experiences: Camp-and Experience Based Weekdays Family Service as a Producer of Social Experience]. Rovaniemi: Lapland University Press.

Martin, C., Hope, S., \& Zubairi, S. (2016). The role of digital exclusion in social exclusion. Scotland: Ipsos MORI.

Niemi, M. (2017). Ikääntyminen ja teknologia - Gerontologisen sosiaalityön näkökulmia [Aging and technology - perspectives on Gerontological social work]. In Kivistö, M. \& Päykkönen, K. (Eds.), Sosiaalityö digitalisaatiossa. [Social work in digitalization. Social science publications]. Yhteiskuntatieteellisiä julkaisuja C 58. (pp. 97-111). Rovaniemi: Lapin yliopisto [University of Lapland].

Nordic Institute for Interoperability Solutions. (2019). https://www.niis.org/. Accessed 29 Sept 2019.

Olphert, W., \& Damodaran, L. (2013). Older people and digital disengagement: A fourth digital divide? Gerontology, 59, 564-570.

Päykkönen, K. (2017). Sosiaalinen media ikääntyneiden kotona asumisen tukemisessa [Social media in supporting older people living at home]. In: Kivistö, M. \& Päykkönen, K. (Eds.), Sosiaalityö digitalisaatiossa. Yhteiskuntatieteellisiä julkaisuja C 58 [Social work in digitalization. Social science publications]. (pp. 125-135). Rovaniemi: Lapin yliopisto [University of Lapland]. https://lauda.ulapland.fi/handle/10024/63035

Peral-Peral, B., Arenas-Gaitán, J., \& Villarejo-Ramos, A. F. (2015). From digital divide to psychodigital divide: Elders and online social networks. Comunicar, Media Education Research Journal, 45, 57-64.

Pohjola, A. (1993). Asiakas sosiaalityön määrittäjänä [Client Defining the Social Work]. In Granfelt, R., Jokiranta, H., Karvinen, S., Matthies, A.-L., \& Pohjola, A. (Eds.), Monisärmäinen sosiaalityö [Multifaceted Social Work]. (pp. 55-91). Helsinki: Sosiaaliturvan Keskusliitto [Finnish Federation for Social Welfare].

Pohjola, A. (2017). Sosiaalityöohjautuva digitalisaation kehittäminen [Social work-driven development of digitalisation]. In Kivistö, M. \& Päykkönen, K. (Eds.), Sosiaalityö digitalisaatiossa. 
Yhteiskuntatieteellisiä julkaisuja C 58 [Social work in digitalization. Social science publications]. (pp. 181-190). Rovaniemi: Lapin yliopisto [University of Lapland].

Siegel, C., \& Dorner, T. E. (2017). Information technologies for active and assisted living Influences to the quality of life of an ageing society. International Journal of Medical Informatics, 100, 32-45.

Sourbati, M. (2007). 'It could be useful, but not for me at the moment': Older people, internet access and e-public service provision. New Media and Society, 11(7), 1083-1100.

Statista. (2018). Forecast of the internet user penetration rate in Finland from 2018 to 2024. https:// www.statista.com/studies-and-reports/. Accessed 16 Sept 2019.

Statistics Estonia. (2019) Statistical Database. Population figure and composition. Modified 09.05.2019. https://www.stat.ee/population. Accessed 16 Sept 2019.

Statistics Finland. (2016). Official Statistics of Finland (OSF): Use of information and communications technology by individuals, 2016 [e-publication]. http://www.stat.fi/til/sutivi/2016/ sutivi_2016_2016-12-09_tie_001_en.html. Accessed 16 Sept 2019.

Statistics Finland. (2019). Official Statistics of Finland (OSF): Population structure, 2019 [e-publication]. http://www.stat.fi/til/vaerak/index_en.html. Accessed 16 Sept 2019.

Turu-uuringute AS. (2019). Nationwide representative survey in Estonia, May.

Vehko, T., Ruotsalainen, S., \& Hyppönen, H. (Eds.). (2019). E-health and e-welfare of Finland (Check point 2018. Report 7/2019). National Institute for Health and Welfare: Helsinki.

VM. (2017). Digituen toimintamalliehdotus [Digital support policy proposal]. AUTA-hankkeen projektiryhmän loppuraportti. Valtiovarainministeriö VM [Final Report of the AUTA Project. Ministry of Finance].

Walsh, K., Scharf, T., \& Keating, N. (2017). Social exclusion of older persons, a scoping review and conceptual framework. European Journal of Ageing, 14(1), 81-98.

Yu, R. P., Ellison, N. B., McCammon, R. J., \& Lange, K. M. (2016). Mapping the two levels of digital divide: Internet access and social network site adoption among older adults in the USA. Information, Communication \& Society, 19(10), 1445-1464.

Open Access This chapter is licensed under the terms of the Creative Commons Attribution 4.0 International License (http://creativecommons.org/licenses/by/4.0/), which permits use, sharing, adaptation, distribution and reproduction in any medium or format, as long as you give appropriate credit to the original author(s) and the source, provide a link to the Creative Commons license and indicate if changes were made.

The images or other third party material in this chapter are included in the chapter's Creative Commons license, unless indicated otherwise in a credit line to the material. If material is not included in the chapter's Creative Commons license and your intended use is not permitted by statutory regulation or exceeds the permitted use, you will need to obtain permission directly from the copyright holder. 